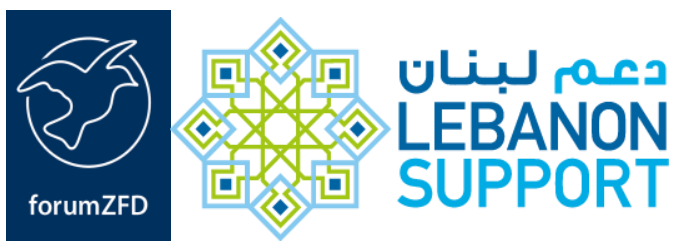

\title{
Contested history, conflicting narratives, and a multitude of initiatives: An analysis of the Mapping of Initiatives addressing Past Conflicts in Lebanon ${ }^{1}$
}

\section{Background}

Over the past decades, Lebanon has witnessed recurring episodes of violence, including internal conflicts, armed clashes, and assassinations (see here the Lebanon Support Mapping of Political Violence in Lebanon (1975-2008)). The Lebanese Civil War (1975-1990) and postwar period generated countless human rights violations, most of which remained unaddressed. An estimated 17,000 civilians were kidnapped or disappeared during the Civil War, and their fate remains unknown until today. Moreover, a general amnesty law for war crimes, issued in 1991, exempted the majority of the protagonists from prosecution and legal liabilities.

While in other post-conflict contexts, inclusive initiatives addressing the past have proven to be rather successful ${ }^{2}$ in dealing with past conflicts and pushing forward efforts for reconciliation, in Lebanon, governments have relied on a top down post-conflict resolution model. The latter considers that "the costs of a process of truth and reconciliation exceed the benefits," 3 and should be sacrificed for the sake of peace and stability. This has led to what many scholars termed a "state-sponsored amnesia"4 accompanied by a lack of justice, reconciliation, and institutional reform, stating that Lebanon has not been able to deal with the past, but is "merely coping with it". 5 The resulting setting is that of a "negative peace", and what was described as the "cold civil peace" during periods of truce throughout the war as well as the post-war period, relying on the mere non-occurrence of violence, in which reconciliation was never fully addressed.

\footnotetext{
${ }^{1}$ This report has been written by Mia Bou Khaled, with the assistance of Sarah el-Masri from Lebanon Support. It is based on the "Mapping of initiatives addressing past conflicts", initiated by forumZFD (Forum Civil Peace Service) in 2015 and then further elaborated by Lebanon Support. It is part of the History of Conflicts project. For further information, explore the project page online, which features, among others, the mapping as well as an infographic summarising the main trends of the mapped initiatives: http://civilsociety-centre.org/hist/.

${ }^{2}$ For instance, in South Africa, the establishment of a Peace Committee has contributed to reduce violence between communities and to create a space for dialogue. Read more about this here: http://www.oecd.org/derec/unitedstates/35112635.pdf

${ }^{3}$ Sune Haugbolle, War and Memory in Lebanon, Cambridge, 2010, Cambridge Middle-East studies, p.70. ${ }^{4}$ Samir Kassir, "Ahwal al-dhakira fi lubnan (The Conditions for Memory in Lebanon)", in Amal Makarem (ed.), Mémoire pour l'avenir, Beirut, Dar al-Nahar, 2002, p.195-204.

${ }^{5}$ Sune Haugbolle, op.cit, 2010, p.2.

${ }^{6}$ Waddah Charara, Al-Silm al-Ahli al-Barid: Lubnan, al-Mujtama' wa al-Dawla, 1964-1967 (The Cold Civil War: Lebanese Society and State), Beirut, Beirut: Ma'had al-Inma' al-'Arabi, 1980.
} 
In spite of this policy of amnesia since the 1990s, several civil society actors have been engaging in initiatives to document, initiate dialogue, support victims, among others, in order to not forget the contested past.

\section{About the mapping}

The "Mapping of initiatives addressing the past in Lebanon" (available here), published by Lebanon Support in partnership with forumZFD (Forum Civil Peace Service) documents initiatives between 1990 and 2017 that aimed at addressing past conflicts and their aftermath in Lebanon. The study, initiated by forumZFD in 2015 and concluded by Lebanon Support in 2018, charts 156 initiatives carried out by individuals, collectives, and organisations whether governmental or non-governmental. Thus, the mapping consolidates, in one openly accessible database, detailed and categorised information about initiatives tackling the past in Lebanon. The mapping does not only serve as a tool for civil society actors, researchers, policy makers, and practitioners in their work on the process of "Dealing with the Past" in Lebanon but also informs the general public about such initiatives.

The data was collected through semi-structured interviews conducted with different actors engaged in the field, in addition to desk research, as well as media monitoring. Lebanon Support and forumZFD developed a typology and coding framework contextualised and adapted from the Conceptual Framework on Dealing with the Past, a holistic approach initiated by Swisspeace. The framework was founded on four principles: the "right to know", the "right to justice", the "right to reparations", and the "guarantee of non-recurrence". This model has been adapted to fit the Lebanese context according to categories that would highlight existing linkages and synergies between these initiatives, as well as thematic areas that have been neglected in Lebanon (the Coding Framework can be consulted here). As such, each initiative was mapped and categorised according to its objective, approach, activity type, target group, launch year, and geographic target, amongst other variables.

This report focuses on the main findings and trends from the "Mapping of initiatives addressing the past in Lebanon", the main actors behind the initiatives, the objectives of such initiatives, as well as initiatives' activities.

\section{Addressing the past, between state passiveness and civil society engagement}

A total of 156 reconciliation initiatives have been mapped in Lebanon since 1990, 47 of which were still ongoing at the time of writing this report. ${ }^{7}$ The majority of initiatives were undertaken by local NGOs (84) with the most mapped actors being ACT for the Disappeared (18), UMAM Documentation and Research (12), and Fighters for Peace (8). Most of the other documented initiatives were led by international NGOs (17), local collectives (15), as well as research institutions (15). In contrast, the Lebanese government has only been involved in 8 recorded initiatives, since the end of the Civil War. These initiatives were mainly series of legislation and

7 This report has been written in August 2018. 
policies aiming to provide support and reparation for victims, such as the establishment of the Ministry of the Displaced as well as the Central Fund of the Displaced in 1993, but also a compensation law in 2001 for former detainees in Israeli prisons.

\section{Countering amnesia: seeking truth and the right to know}

Truth seeking and right to know was the objective of 129 initiatives, which aimed at fostering individual and collective knowledge regarding human rights violations that took place during the Civil War and post-war period. At the same time, only 17 initiatives sought reparation for the victims by providing them with compensations and psychosocial support. Lastly, justice and non-recurrence was the least frequently mapped objective, with only 10 initiatives aiming to contribute to the non-recurrence of past human rights violations through mostly a series of legislations and laws (read more about this below).

As such, the data mapped points to a considerable number of truth-seeking initiatives which can be read within the context of the aforementioned amnesty law and state imposed amnesia, as to this day, many of the human rights violations have not been tackled officially.

The state's mantra of "la ghalib, la maghloub" (no victor, no vanquished), became the "official justification for such transition from war to peace" 8 without accountability for the past. Lebanon is therefore characterised by a multitude of "memory cultures" on past conflicts, rather than a collective memory or an official historical narrative of the Civil War.

For instance, when general amnesty was granted by the state, no conditions were imposed on disbanded militias obliging them to provide information on the fate of their victims. Despite the mobilisations of families of the kidnapped and disappeared ${ }^{9}$ to pressure the government to clarify the fate of their relatives, no serious measures were taken by the government to investigate the fate of missing persons during the Civil War and post-war period.

In 2000, under the pressure of public protests organised by families of the disappeared, a "Committee of Inquiry in the Fates of the Missing and Forcibly Disappeared" was created by the government. However, the Committee did not divulge the fate of any missing person nor had taken any measure to exhume bodies or protect the sites, even though it was the first time a governmental body recognised the existence of mass graves. Additionally, in 2014, the State Shura Council issued a decision binding the government to disclose the case files investigated by the Committee. After a judicial battle and a prior refusal by the government to disclose these files, families were finally allowed to access copies of investigation documents. Nevertheless, according to Wadad Halwani, head of the Committee of the Families of the Kidnapped and

\footnotetext{
${ }^{8}$ Sune Haugbolle, op.cit, 2010, p.71.

${ }^{9}$ Families of the kidnapped and disappeared have been mobilising since 1982, within the "Committee of the Families of kidnapped and disappeared" in Lebanon, founded during the same year in response of the growing number of missing persons during the Civil War (read more about it here).
} 
Disappeared in Lebanon, these files showed that the government has not conducted any serious investigation. ${ }^{10}$

All this comes in contradiction with approaches to post conflict resolution in other countries and contexts, as well as international literature on the subject, which all stress on the importance of "recognition before reconciliation". 11 Indeed, ensuring the right to know implies the acknowledgment of past human rights violations, which in turn provides closure for victims, and allows for proper mourning, in addition to personal and collective healing.

The observed focus on truth-seeking initiatives can, thus, be understood in a context of state apathy in the process of reconciliation, and specifically in the urgency of ensuring the mere right to know.

\section{Reconciling with the past: A variety of approaches}

According to the mapping, actors have diversified their initiatives' approaches. As a result, no dominant trend in the approaches has been recorded.

For initiatives seeking truth and the right to know, the three most frequently mapped approaches were cultural production (31), documentation (30), and dialogue and reconciliation (23). A large number of cultural products have been created around the theme of the Lebanese Civil War including books, comics, photos, paintings, movies, plays, and others. Nonetheless, in this mapping, only movies, exhibitions and plays that directly focused on past conflicts and the postwar period were included. Still, the study mapped a significant number of cultural products. This could be seen as an attempt by artists to counter the Civil War's unresolved parcels of memory and to forge their own.

As for reparation initiatives, mainly approaches relevant to psychosocial support (7), and memorials and commemorations (6) were adopted. For instance, Act for the Disappeared inaugurated several memorials between 2015 and 2016 in different areas such as Tyre, Jbeil, and the Palestinian Burj Shmali camp. Interestingly, the memorials and commemorations were all initiated by civil society, which confirms the lack of state-led remembrance initiatives and policies.

\footnotetext{
${ }^{10}$ According to Wadad Halawani, these files contained lists of names of disappeared persons, dates of abductions, administrative correspondence, and names of suspects. However, no investigations were conducted among these suspects in order to unveil the fate of missing persons. (Read the full statement of Wadad Halawani on handover of Dossier on Fate of Disappeared here: http://legalagenda.com/en/article.php?id=653\&folder=articles\&lang=en)

${ }^{11}$ For instance, it has been common to establish independent "Truth and Reconciliation Commissions" following internal armed conflicts, in order to investigate widespread Human Rights violation such as enforced disappearance, massacres, and other crimes. These commissions provide victims with acknowledgement and recognition of their suffering which can enable them to engage with the reconciliation process. Some notable examples of truth commissions include the former Yugoslavia, South Africa, and Sierra Leone among many others. (Read more about Truth and Reconciliation commissions here: https://www.ictj.org/gallery-items/truth-commissions)
} 
At last, justice and non-recurrence initiatives employed approaches mainly relevant to amnesty and laws (6). Among these was the government's issuance of a number of policies and legislations, such as the general amnesty law that exempted the majority of Lebanese war protagonists from prosecution. This amnesty law ought to be read in a context where post conflict political power sharing has been arranged among war protagonists, as well as those responsible for war crimes and human rights violations. Indeed, these former warlords "would have been the first to be prosecuted in case of trial"12, which would have disrupted the existing power structures.

\section{Documenting the past: A need to discuss memory}

The main activities adopted by non-governmental organisations were public forums (45), closed forums (34), and research (20). Most of the organised public forums were related to cultural production targeting the general public, while closed forums aimed at creating dialogue, raising awareness, or informing action amongst a specific target group such as scholars, experts, students, and teachers among others. Research activities mainly had a documentation purpose, such as recording oral history projects, collecting testimonies, and producing documentaries. All of these activities reflect on the need to document and engage the dialogue around past conflicts and human rights violations. Again, these activities can be read as attempts by civil society actors to compensate the lack of official discussion and memory about the Civil War.

\section{The importance of youth involvement for conflict prevention}

Most of the mapped initiatives had a nationwide outreach (95) and were not targeting any specific region. About 40 initiatives were implemented in Beirut, whereas the North, the South, and Mount Lebanon only saw 11, 11, and 8 initiatives. The resurgence of punctual bursts of violence across the country (such as the recurring violence in Tripoli), and the use of narratives and discourses from the Civil War, tend to indicate that conflict lines and narratives inherited from the Civil War constitute a fertile ground for further violence in the country.

Most initiatives were targeting the general public (59), however, a considerable number of initiatives were targeting youth (34), professionals (30), and teachers (10). Due to the absence of a national history curriculum and the lack of educational tools addressing the Civil War period, organisations have been raising awareness, informing, and training professionals and teachers about the process of "Dealing with the Past" through closed forums and capacity building sessions. For instance, in 2009, the Lebanese Foundation for Permanent Civil Peace (LFPCP) organised training sessions for lawyers and judges on transitional justice mechanisms.

As for the youth, although not having lived the Civil War, they are still living within its long lasting aftermath and the permanence and reproduction of conflict narratives. In fact, they have been witnessing the war's unfolding consequences, such as sectarian and political antagonisms,

${ }^{12}$ Sune Haugbolle, op.cit, 2010, p.71. 
without any official narrative available to navigate their history, and have been vulnerable to political manipulation and more likely to engage in violence. As such, many historians and political scientists believe that future generations should be informed about the Civil War, so as not to repeat it in the history of Lebanon. Initiatives have, hence, sought to involve youth in reconciliatory initiatives.

\section{A turning point: 2005 and the emergence of new initiatives}

After the end of the Civil War, only ten initiatives were launched between 1990 and 1999. Although reconciliation is a long-term process that requires time to unfold, especially given the often volatile environment in a post-conflict context, this small number of reconciliation initiatives appears to also be the result of a tendency of censorship and self-censorship in Lebanon. ${ }^{13}$ For example, in 1994, a broadcasting law prohibited the media to transmit "any matter seeking to inflame or incite sectarian or religious chauvinism" which had made efforts to have any public discussions about the War very difficult. ${ }^{14}$

However, in 2000, after the liberation of the South from the Israeli occupation ${ }^{15}$ the number of initiatives increased slightly, with six new initiatives launched during that year. Indeed, this event seems to have stirred small debates on unresolved issues from the War, and some formerly silenced discussions "were opened and added to the willingness to publicly remember the war."16

A peak of 19 initiatives has been mapped between 2005 and 2014. A willingness to confront the past seems to have arisen after the assassination of former Prime Minister Rafik Hariri in 2005 and the subsequent withdrawal of the Syrian Army. ${ }^{17}$ The withdrawal of a foreign power from Lebanon, namely the Syrian Army, instead of improving a consolidation of peace and the return of Lebanese sovereignty, initiated a period of insecurity, vulnerability, and instability. Indeed, the country witnessed a series of political assassinations, sectarian tensions, a war with Israel (2006), armed clashes between Lebanese Armed Forces (LAF) and an extremist militia (Fateh elIslam) in the Palestinian Nahr el-Bared camp (2007), clashes between the LAF and armed militant groups in Tripoli (2014), and numerous other incidents. ${ }^{18}$

All these events seem to have contributed to reviving old hostilities proving to many that the divides of the Civil War were still present and capable to be used in the minds of Lebanese

\footnotetext{
${ }^{13} \mathrm{lbid}$, p.72.

14 Ibid.

${ }^{15}$ Amid the Lebanese Civil War hostilities, Israel invaded Lebanon in 1982 and remained in control of the Lebanese Southern borders until the year of 2000.

16 Ibid.

${ }^{17}$ Syria entered Lebanon in 1976 as part of an Arab peacemaking force, thus making the occupation legitimised. The Syrian Army was to gradually withdraw two years after the Ta'if agreement ending the War in 1989. However, it remained present 15 years later, until 2005, when the UN passed a resolution calling for Syria's immediate withdrawal from Lebanese territories.

${ }^{18}$ To learn more about contemporary conflicts dynamics in Lebanon, explore Lebanon Support's Conflict Analysis Project page online: https://civilsociety-centre.org/cap.
} 
people. Consequently, addressing the root causes of conflicts through reconciliatory initiatives seems to have been a driving priority for many organisations and activists in Lebanon engaged in peacebuilding, social stability, and conflict transformation.

\section{Conclusion}

Reconciliation in Lebanon has faced many challenges such as a state imposed amnesia, unresolved human rights violations, and a lack of accountability of the perpetrators of these violations. Despite civil society's efforts to address the contested past in Lebanon, the limited education and awareness about past conflicts remains omnipresent. Therefore, the information conveyed by this mapping aims to provide practitioners, researchers, civil society actors, and policy makers with better knowledge and analysis about processes and developments concerning "Dealing with the Past" in Lebanon. This openly accessible data can be used by those developing new relevant initiatives and interventions to fill gaps and complement existing efforts, thus contributing to transforming and overcoming past conflicts and long term divisions. 